\title{
THE USE OF NATURAL FIBER AS A BARRIER TO GARBAGE IN AMAZON URBAN RIVERS
}

\author{
LUCAS MATHEUS S. P. RODRIGUES \& JUSSARA SOCORRO CURY MACIEL \\ Federal Center for Technological Education of Amazonas, Brazil
}

\begin{abstract}
The main cities in North Brazil, located in the Amazon rainforest, have sanitation and flooding problems caused by accumulating waste and garbage, particularly in poor neighborhoods. This includes Manaus, the capital Amazonas, which has recently had obstruction problems caused by accumulating waste. Nowadays, dredging waste collection systems have annual costs of around $\$ 11$ million Brazilian Reais. This kind of garbage collection degrades natural protection provided by vegetation in drainage beds and serves as a stopgap measure to reduce local pollution of rivers. The city of Rio de Janeiro created an initiative to clean the Guanabara Bay in time for the 2016 Olympic Games, named "Plano Guanabara Limpa" (Clean Guanabara Plan): it used barriers installed before the river's mouths, collecting 300 tons of different garbage per month. This research aims to analyze the use of natural fiber jute on woven networks, installed in the cross channel to prevent the flow of waste to the Negro river. The proposed garbage collection system is sustainable, biodegradable and low-cost, using local raw materials that can be found and produced in the Amazon region, promoting planting, production, and manufacture by riverside communities. Based on such, this study will address the inclusion of natural fiber barrier networks, resulting in better economy and sustainability to the region. This study is based on the conceptual approach, application, and viability of literature, as well as research in other implementation models of garbage collection to propose a prototype design, using mapping satellite images and local data collected in the natural drainage of Manaus. The research proposes a preliminary model that can be adapted to any urban channel of the Amazon rainforest. Wrong solid waste disposal in the city drainage that flows in the Negro river causes problems that the local government and society currently deal with. The solution presented combined public policy awareness and new alternatives for environmental management, enables the natural barrier garbage system, blocking the passage of discarded materials to the river, offering points of selective waste collection and scroll recycling.
\end{abstract}

Keywords: pollution control, natural fiber, Amazon urban rivers, natural drainage.

\section{INTRODUCTION}

Sanitation problems are usually present in the main cities in the north of Brazil; one of such examples is Manaus, located in the Amazon rainforest. These problems are more evident in poor neighborhoods, where garbage is thrown in natural drainage systems, locally called "Igarapés". Annual solid waste removal in Igarapés generates a significant cost for the municipal government.

According to data from the Municipal Department of Urban Cleaning of Manaus [1], 18 tons of garbage were daily removed from urban rivers between January and May of this year, totaling 2,441 tons dredged from bodies of water in the city of Manaus. It is highlighted as one of the most expensive public cleaning modalities in the world, at an estimated cost to municipal public coffers of approximately US $\$ 300$ thousand per month.

The environmental issue is assuming a bigger importance among the great preoccupations of the contemporary world. The unbridled human intervention, ecological imbalances, and environmental degradation are the governments' and civil society's guidelines [2]. 
In addition to the landscape impact issue, the waste accumulation can lead to problems to the population during the rainy season, since Igarapés represent the local drainage system, and once clogged can create floods in these populated areas.

Marques and Oiagen [3] state that, during winter seasons with morbid rainfall rates, streams that have been incorrectly deposited with large amounts of garbage are flooded due to the lack of flow drainage, since garbage obstructs the bed of the streams. This makes a chaotic situation, which overflows water and invades the nearby houses, taking all garbage that was thrown in the river, bringing a series of diseases to the people who live there, impairing the quality of life.

Guanabara is the second largest bay in the Brazilian coast. It was included in a decontamination program, part of the largest set of environmental recovery of the last decade in Rio de Janeiro, Brazil. The program aims to rescue the ecosystems around the Guanabara Bay and gradually recover the water quality of the bay and the rivers that flow there, through the construction of adequate sanitation systems [4].

The basic sanitation works had an investment of 1.5 billion Brazilian Reais for the Rio 2016 Olympic Games, and works of the Environmental Sanitation Program with the Municipalities of Guanabara Bay (PSAM) had an investment of about 1.13 billion. The main goal was to clean up $80 \%$ of the Bay until the Olympic Games, according to information from the State Government and the City Hall of Rio de Janeiro [5].

There are specificities and obstacles found by the lack of action planning, high investments, adequate management, continuity, monitoring, control, and also partnerships with Research Institutes and Universities [5].

Factors responsible for the discharge of 18,000 liters per second of sewage in Guanabara Bay are related to the lack of public awareness and the environmental sanitation of nearby municipalities. 10 thousand liters out of the total sewage is not treated, which demonstrates the inefficiency of government programs. This situation contributed to the noncompliance with the pollution control goal, which was $80 \%$ of the effluents launched in the bay [5].

Sanitation measures, garbage collection, environmental education and sewage treatment plants are also important to achieve the goal of permanent decontamination [6]. The main urban infrastructure systems, such as the environmental sanitation, are directly related to the natural resources and the health of the population [7].

Revitalization and de-pollution actions relied on barriers made out of synthetic materials of networks that retain the floating garbage. With a grid shape, the containment barriers were initially woven from strong, non-biodegradable, geosynthetic structures that form a three-dimensional hive-shaped mattress. Ecobarriers are currently made from recycled synthetic materials, however, there is an immediate need for resistant biodegradable materials that wipe away waste without reducing efficiency [8].

Natural fibers are raw materials of high quality. The use of natural fibers in coatings is of ancient practice in the world, and the increasingly fiber use such as sisal, coconut, cotton, and jute has become diversified [9].

The success of Brazil's jute industry came about because of ideal environmental conditions along the Amazon River floodplain. Jute needs silty-clay soils, hot (at least $26^{\circ} \mathrm{C}$ during the growing season), and humid conditions. The latter is especially important after germination [10].

Jute is a crop adaptable to the floodplain environment, and, as long as deforestation is contained, it could be environmentally sustainable and an excellent land-use for the region. The historical geography of jute in the Amazon is a tale of the interweaving of a crop and people from places far apart, yet bound together in a global economy [10]. 
In recent years, the development of new fibers and their applications have acquired an important role, due to the new technologies and cutting-edge materials use. This is the case of fiber materials used for agriculture, and especially for environmental protection [9].

The main properties of these fibers are tensile strength, flexural strength, fracture toughness, and resistance to fatigue, impact, and thermal shock. Natural fibers are gaining importance in this application due to various advantages over synthetic fibers such as low cost (due to abundance), biodegradability, flexibility, low density, relatively high tensile, and flexural modulus, minimum health hazards, etc. Thus, natural fibers can be used economically, effectively [11].

Jute, cotton, sisal and coconut are some of the natural fibers that can be used as reinforcement for plastics, especially for applications whose conditions of use are less severe, in the case of partial and even complete replacement of synthetic fibers [12].

However, in most cases, the use of vegetable fiber in Brazil still remains in conventional applications, such as in the yarn production for garlands, garments, handicrafts and clothes. This makes it possible to consider that these natural resources are not yet properly exploited, taking into account that Brazil is one of the countries that has one of the largest plant biomass in the world and has the fifth largest overall territorial extension [12].

Vegetable fibers are the most commercially important fibers with a potential use in composite materials. Jute fibers (Corchorus capsularis), for instance, have a high world annual production of about 2,300 (103 ton.). These fibers offer several advantages in comparison to synthetic fibers, such as being biodegradable, non-abrasive to processing equipment, and $\mathrm{CO}_{2}$ neutral. Furthermore, they are an important source of income for agricultural societies. Still, they are light weight and have high specific strength [13].

Another great advantage of the vegetable fiber is their low cost and the positive social impact. They are native plants of many countries and have been used for decades in the textile and paper industries. Brazil has a potential to produce about 10,000 ton/year of vegetable fibers that can be natively found or cultivated, becoming a source of income for several local communities [13].

The use of natural fibers in the most diverse segments promotes a sustainable and environmentally friendly economic development, giving favorable opinions to the application feasibility and future research of issues to be fixed and/or improved with other natural fibers, such as waste barriers in urban streams.

The premise of this article is to present an innovative and sustainable proposal: the use of natural fiber barriers, jute, to retain garbage, which also encourages the study of other fibers in the Amazon region, such as mauve and bamboo. This project can influence the social inclusion of river area residents in weaving processes, network installation, and garbage removal, generating employment and income. In addition, it will improve the local production characterized by the jute utilization. It would be interesting if the networks of synthetic materials were replaced by absorbent, renewable, adaptable plant materials that decompose within the ecological cycle and promote social and environmental development.

\section{METHODOLOGY}

This study is based on literature research related to river pollution control using physical barriers. It was noticed that the methods applied are made of synthetic materials. In Brazil, and in the Amazon rainforest, there are collections of input that can generate natural fibers such as jute (corchorus capsularis), mauve (malva sylvestris), babaçu (attalea speciosa), bamboo (bambuseae), among others. In this research, in particular, it was decided to use jute, due to the ease of working with the network and fiber strength. 
One of the functions of natural fibers is the geotextile, which is used to improve the structural yield of soils, and the filter, allowing a passage of water while preserving as structural features of the adjacent soil. They can also be made from cereal straw, coconut, hemp, flax, cotton, sisal, wood fibers, banana, and other materials [7].

Initially, research was carried out in other models for the implementation of waste collection systems to propose a prototype project, using satellite image mapping and the local data collected in Manaus's urban rivers.

In this sense, the decontamination actions adopted in Rio de Janeiro were analyzed. According to the results observed, it was determined that the decontamination plan used physical-chemical methods, an enclosing of large amounts of garbage deposit sites in the surroundings, and use of 10 eco-barges to collect floating trash. However, this system failed to accomplish $80 \%$ of the organic load removal from Guanabara Bay waters.

In Manaus, the length of the urban rivers reaches a total of 70 kilometers, or about 44 miles. It is estimated that, in this area, there are around 400,000 inhabitants with no shelter or any basic sanitation instrument, including water and sewage [14]. The research of this article is focused on these urban channels that accumulate garbage.

This research proposes a preliminary model that can be adapted to any urban channel of the Amazon region. The pollution data is referenced through public environmental agencies or municipal public institutions. Also, the data collected at the sites, serving as a base template, was measured and its background quota estimated to prepare the structures prototypes simulation to remove accumulated garbage.

Today, river streams are polluted, with channels blocked by heavy garbage, and inoperative garbage collection systems. The absence of sanitation and sewage systems contribute to our natural drainage channels' destruction. The idea of barriers comprises holes, similar to geogrids, retaining only the waste, while preserving the water flow and aquatic biodiversity.

São Raimundo river is one of the most important urban rivers in Manaus, drained by the Mindu basin, both of which are obstructed by large amounts of garbage caused by poor infrastructure in sanitary services and the local population's lack knowledge on how to deal with this problem. The São Raimundo river is one of the most extensive urban rivers in Manaus, where the data has been collected, and is a common watercourse in the region that daily discharges heavy solid waste loads in the Rio Negro. In the floating garbage collecting network projection, the area near São Raimundo bridge was chosen. It is approximately $1 \mathrm{~km}$ from the stream mouth, with an estimated width of 102 meters and length of about 211 meters.

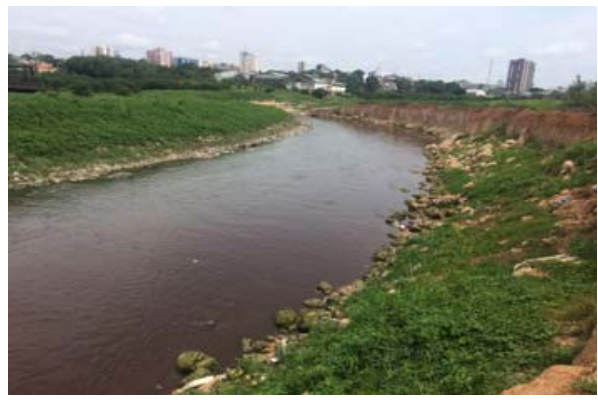

Figure 1: São Raimundo River, Manaus, Brazil. Own work from the author.

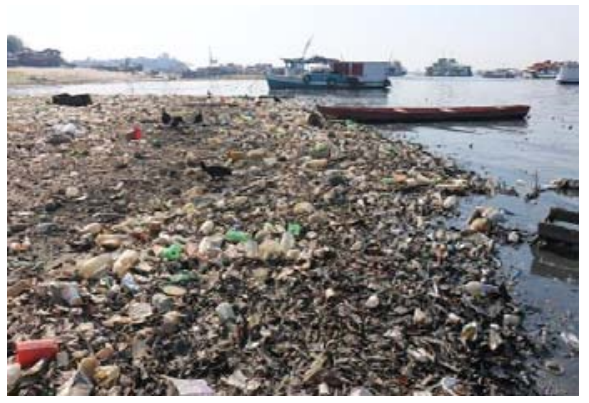

Figure 2: Educandos River Mouth, Manaus, Brazil [15]. 


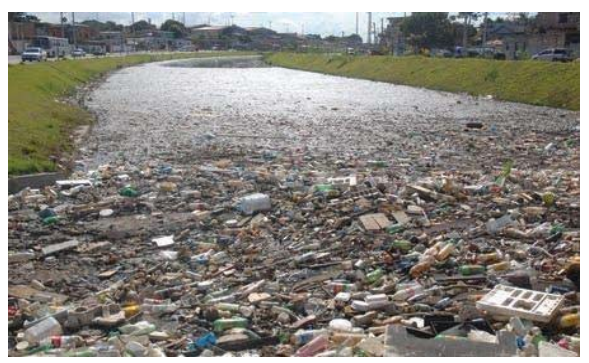

Figure 3: Quarenta River, Manaus, Brazil [16].

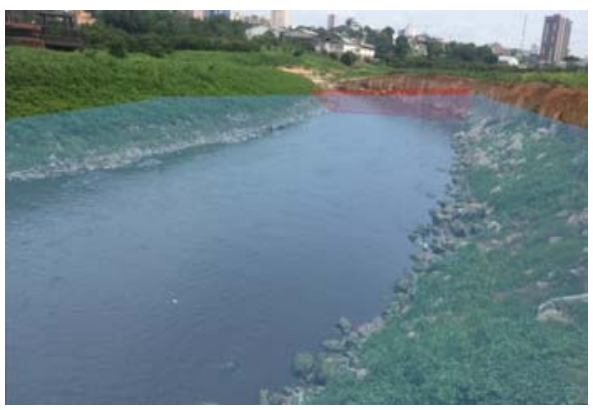

Figure 5: Sketch project of garbage collection network with natural fiber in São Raimundo stream.

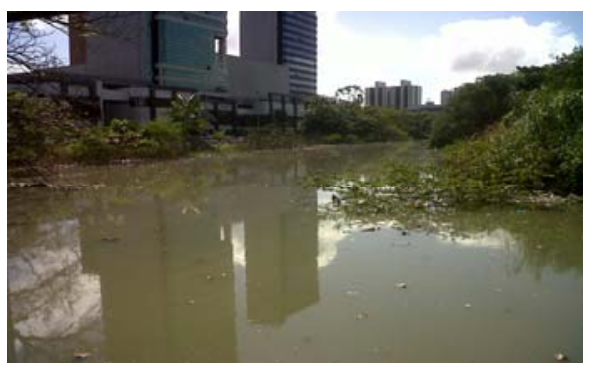

Figure 4: Mindu River, Manaus, Brazil. [17]

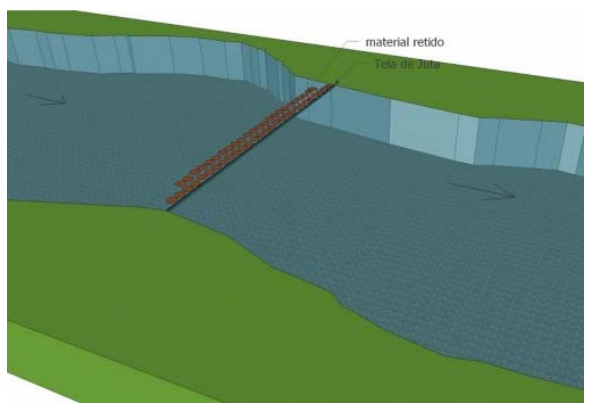

Figure 6: Containment barrier design with natural fiber in Sketch Up software.

The Sketch Up software was used in this project, because it has a simple interface, it is easy to execute, and has a large collection of electronic library models.

As previously mentioned, the garbage collected from natural waterways in Manaus is 18 tons per day; the river obstructions are a serious socio-environmental problem, so the importance of having a physical barrier with cheap and regional materials, causing no damage to aquatic species.

Thus, it was thought to use natural fiber, which could generate a type of network manufactured in the region itself to function as a garbage barrier. Some types of fibers were studied, as well as their characteristics, in order to elaborate a prototype of the cheap network to be used in the channel.

\section{ANALYSIS OF THE ENVIRONMENTAL VIABILITY OF NATURAL FIBER NET}

Plant fibers are designated as lignocellulosic materials. Some occur spontaneously in nature, others are cultivated through agricultural activities, and some of them are produced in the agroindustry [18]. They are environmentally friendly materials due to their biodegradability and potential for reuse [19]. Some of the natural fiber applications are the geotextiles, absorbent structures and water filters. 
According to Oashi [9], sisal geotextiles, for instance, are completely biodegradable products without the addition of any synthetic material. Their structures can be manufactured in different weights and configurations, so that each product has a specific design depending on its final use.

Fibers are tough, last long, and have a great lift capacity. They take 4 to 10 years to decompose. Some high-density matrices are produced to deal with adverse situations such as dry, marshy, or still frozen places. The quality of the products persists even when submerged [7].

They stand out as sorbents and, besides replacing the use of synthetic materials, present low cost and aggregates value to the residual biomass that accumulates garbage in the main Brazilian cities.

Viability is based on regional jute production. The highest recorded production of jute occurred in the Solimões river during the 1990s. The jute and mauve planting in the state of Amazonas has been characterized by its high growth capacity in floodplain lands, typical of the region, where it presents sediments in suspension, thus providing a soil that is fertile enough for its production. The strength of the fiber adds value to the production of these species for bag manufactures [20].

The jute and mauve culture in Amazonas had a great development due to the fact that it became a profitable route. Even though they are also produced in the states of Para and Maranhão, it is in the Amazonas state that the greatest production occurred [20].

However, Brazil has reduced its jute and mauve production in the last decade at the time of decline in world production. However, Brazil's domestic consumer market is still largely dependent on raw jute imports from Bangladesh [21].

Jute fibers need to be used based on a sustainable system to avoid the Amazon deforestation. Examples of such raw material sources are annual growth native crops/plants/fibers, which are abundantly available in tropical regions over the world. These plants/fibers (like jute and sisal) have been used for hundreds of years for many applications such as ropes, beds, bags, etc. These renewable, non-timber based materials could reduce the use of traditional materials such as minerals and plastics for some applications [13].

The jute fibers are strong and so are suitable for the resistant nets production in the drainage channels. Besides being resistant, economic, and versatile, they are also biodegradable [22], [23].

Jute is a versatile and environment-friendly natural fiber that generates diversified valueadded products. It falls into the best fiber category long with kenaf (Hibiscus cannabinus L.), industrial hemp (Cannabis sativa L.), ramie (Boehmeria nivea L.) and banana (Musa acuminata colla) fibers [24].

Besides ecological considerations, natural fibers exhibit many advantageous properties which promote the replacement of synthetic fibers in polymer composites. They are a lowdensity material yielding relatively lightweight composites with high specific properties and therefore natural fibers offer a high potential for an outstanding reinforcement in lightweight structures. Natural fibers are derived from a renewable resource and do not have a large energy requirement to process [25].

This plant cultivation is typical to hot and humid climates, and mainly (mechanically) cultivated in the Northern region of Brazil, with quasi or completely manual planter use, with the own population riverside, with the production tradition. It adapts better in fertile, flood-prone, floodplain areas, which is typical of the Amazon region. 
In addition, the jute network could be built and installed in the urban channels by riversides, coordinated by the joint action of public power, private initiative, and industries, with investments in manufacturing improvement and cost subsidies.

The seed development cycle is approximately eight months, with harvests from July to August. These are produced under the order of Natural Fibers Production Fostering Institute in Amazonas, that demands from fiber producers located in Parintins and Manacapuru. They also request jute seeds from the Government of the State of Amazonas through the Amazon Development Institute and private firms [21].

The state of Amazonas shows great possibilities of being inserted in a process of highly productive agricultural development, due to its regional potentialities. On this perspective, the production of jute and mauve is indicated, as a productive activity that is conditioned by the water annual cycle that fertilize the flood lands where these plants are cultivated [20].

Natural fibers are classified according to their extraction: seed, stem, leaves, or fruits. The main advantages are the abundance, low cost, low bulk density, carbon dioxide absorption capacity of the environment, biodegradability, and renewability [26].

The mechanical properties of natural fibers are influenced by the chemical composition related mainly to cellulose and lignin content by the orientation of crystals and by the degree of crystallinity, and these factors are dependent of type of plant, conditions during growth as well as extraction methods used [27].

Since quality and production efficiency of these fibers depend on natural conditions it may become difficult to predict their exact behavior. The heterogeneity of the properties of these fibers subject to different extraction, production, and processing techniques poses a problem. These are some of the issues that have not been addressed and can be the subject of further studies [11].

Table 1 shows the natural characteristics of the main fibers according to extraction, cost, use and resistance data in order to analyze the fiber to compose the network.

According to the Table 1 analysis, the most resistant fibers are jute and mauve. The jute fiber had the best result in relation to the local culture tradition and large demand for use, besides an easy extraction processes and a rapid harvest cycle, depending on the fluvial regime and not rainy or dry seasons. The mauve fiber presents lower resistance than jute. The piaçava requires time for harvest. Sisal requires semi-arid climate regions and it is not applied to Amazon region. And the other fibers are not traditional in the Amazon.

\section{CONCLUSIONS}

The analysis of the different natural fibers allowed us to conclude that jute is the most useful fiber for this project, as it is highly resistant and also is traditionally planted in the state of Amazonas, which presents viability and low cost.

The environmental contributions of jute, such as biodegradable and renewable aspects, and other benefits for local artisanal confection, qualify the fiber to be implanted as a physical barrier against urban waste in small rivers.

Further research about environmental characteristics of the streams will be made in the next stage with the support of equipment from the Geological Survey of Brazil (CPRM): pollution data; flow velocity using flowmeter equipment; Acoustic Doppler Current Profiler (ACDP), extension, width, depth, diversity of aquatic species and vegetation coverage.

The jute used in a garbage barrier network in streams of Manaus is feasible and adaptable to any urban channel, such as the synthetic barrier model adopted in Rio de Janeiro. The nets are fixed in barrels on the river banks. Eco boats collect the garbage, which is taken to recycling centers or usable in local craft workshops. 
Table 1: Characteristics of the natural fiber [28]-[31].

\begin{tabular}{|c|c|c|c|c|}
\hline Natural fibers & $\begin{array}{c}\text { Raw material } \\
\text { extraction }\end{array}$ & $\begin{array}{c}\text { Economic and } \\
\text { environmental cost }\end{array}$ & Use & Modules [23] \\
\hline Jute & $\begin{array}{l}\text { Cultivated in hot and } \\
\text { humid climate regions. } \\
\text { Extraction by the } \\
\text { maceration process. } \\
\text { Obtained by regional } \\
\text { procedure. }\end{array}$ & $\begin{array}{l}\text { Low environmental } \\
\text { cost, biodegradable } \\
\text { and does not need } \\
\text { artificial fertilizers in } \\
\text { planting. Great } \\
\text { economic use. }\end{array}$ & $\begin{array}{l}\text { Textile and other } \\
\text { industrial uses }\end{array}$ & $\begin{array}{l}\text { Tensile strength } \\
\text { modulus } 320-500 \mathrm{MPa} \\
\text { Elasticity Modulus } 12- \\
100 \mathrm{GPa} \text {; Strain at break } \\
(\varepsilon \mathrm{T}(\%)), 1.3 \text { to } 2.8 ; \text { And } \\
\text { the specific mass } 1.5 \\
\mathrm{~g} / \mathrm{cm}^{3}\end{array}$ \\
\hline Malve & $\begin{array}{l}\text { Cultivated in hot and } \\
\text { humid climate regions. } \\
\text { Extraction by the } \\
\text { maceration process as } \\
\text { well. Requires a } \\
\text { potassium-rich soil for } \\
\text { planting. }\end{array}$ & $\begin{array}{l}\text { Great economic use. } \\
\text { Low environmental } \\
\text { cost. Natural, does not } \\
\text { cause environmental } \\
\text { impact. }\end{array}$ & $\begin{array}{l}\text { Textile and other } \\
\text { industrial uses }\end{array}$ & $\begin{array}{l}\text { Tensile strength } \\
\text { modulus, } 160 \mathrm{MPa} ; \\
\text { Elasticity modulus } 17.4 \\
\text { GPa; Strain at break ( } \varepsilon \mathrm{T} \\
(\%) \text { ), } 5.2 ; \text { And the } \\
\text { specific mass } 1.41 \mathrm{~g} / \mathrm{cm}^{3}\end{array}$ \\
\hline Sisal & $\begin{array}{l}\text { Cultivated in regions } \\
\text { with semi-arid climate. } \\
\text { Permanent year-round } \\
\text { extraction }\end{array}$ & $\begin{array}{l}\text { Great economic usc. } \\
\text { Low environmental } \\
\text { cost. Does not cause } \\
\text { environmental impact }\end{array}$ & $\begin{array}{l}\text { Textile and other } \\
\text { industrial uses }\end{array}$ & $\begin{array}{l}\text { Tensile strength } \\
\text { modulus, } 126-800 \mathrm{MPa} ; \\
\text { Elasticity modulus } 3,8- \\
62 \mathrm{GPa} \text {; Strain at break } \\
(\varepsilon \mathrm{T}(\%)), 2,8-10, \text { And the } \\
\text { specific mass } 1,27-1,5 \\
\mathrm{~g} / \mathrm{cm}\end{array}$ \\
\hline Bamboo & $\begin{array}{l}\text { Cultivated in tropical } \\
\text { and subtropical climate } \\
\text { regions. Extraction by } \\
\text { maccration process. }\end{array}$ & $\begin{array}{l}\text { Great economic use. } \\
\text { Low environmental } \\
\text { cost. }\end{array}$ & $\begin{array}{l}\text { Textile, industrial } \\
\text { uses and civil } \\
\text { construction, with } \\
\text { ecological } \\
\text { construction, and } \\
\text { picces of furniture }\end{array}$ & \\
\hline Babaçu & $\begin{array}{l}\text { Fruits and almonds } \\
\text { extraction, which takes } \\
\text { place at the age of } \\
\text { eight. Little cultivated. }\end{array}$ & $\begin{array}{l}\text { Great economic use. } \\
\text { Low environmental } \\
\text { cost. }\end{array}$ & $\begin{array}{l}\text { Textile and chamical } \\
\text { industrial witch the } \\
\text { use of biodiesel }\end{array}$ & \\
\hline Coconut & $\begin{array}{l}\text { Cultivated in tropical } \\
\text { climate regions. } \\
\text { Extraction process of } \\
\text { linen spinning. }\end{array}$ & $\begin{array}{l}\text { Great economic use. } \\
\text { Low environmental } \\
\text { cost. It is } \\
\text { biodegradable. }\end{array}$ & $\begin{array}{l}\text { Textile and other } \\
\text { industrial uses }\end{array}$ & $\begin{array}{l}\text { Tensile strength } \\
\text { modulus, } 95-149 \mathrm{MPa} ; \\
\text { Elasticity modulus } 2,8 \text { - } \\
13,7 \mathrm{GPa} \text {; Strain at break } \\
(\varepsilon \mathrm{T}(\%)), 3,3-5,1 ; \text { And } \\
\text { the specific mass } 1,18- \\
1,45 \mathrm{~g} / \mathrm{cm}^{3} \\
\end{array}$ \\
\hline Piaçava & $\begin{array}{l}\text { It is cultivated on very } \\
\text { fertile soils. It does not } \\
\text { require significant } \\
\text { financial resources for } \\
\text { planting and is } \\
\text { harvested once a year. }\end{array}$ & $\begin{array}{l}\text { Great economic } \\
\text { exploitation in the } \\
\text { industrial fibers } \\
\text { extraction. Low } \\
\text { environmental cost; } \\
\text { Does not use fertilizers } \\
\text { for planting. }\end{array}$ & $\begin{array}{l}\text { Used in the } \\
\text { industrial and } \\
\text { domestic brooms } \\
\text { manufacture; it } \\
\text { brushes and covers } \\
\text { specific types of } \\
\text { residence in general. }\end{array}$ & $\begin{array}{l}\text { Tensile strength } \\
\text { modulus, } 143 \mathrm{MPa} ; \\
\text { Elasticity modulus } 5,60 \\
\text { GPa; Strain at break ( } \mathrm{ET} \\
(\%)) 5,9 ; \text { And the } \\
\text { specific mass } 1,05 \mathrm{~g} / \mathrm{cm}^{3}\end{array}$ \\
\hline
\end{tabular}


Fiber barrier implantation in urban channels also creates the possibility of social projects with local residents in the fiber weaving, generating employment, income, and environmental educational awareness.

Therefore, the natural fiber network is highly important to prevent the coarse debris from continuing to flow to, or being retained near banks of, the Negro river, further preventing a disruption to the environment and landscape of the region. Hence, with a simple technology, the garbage can be removed from urban rivers by the community itself or by public means. This material can also be adapted for collections with boats or ecoboats.

\section{REFERENCES}

[1] Secretaria de Limpeza Urbana de Manaus. Available at: http://semulsp.manaus. am.gov.br. Accessed on: Nov. 2016.

[2] Coelho, M. Impactos ambientais em áreas urbanas-teorias, conceitos e métodos de pesquisa. Urban environmental impacts in Brazil. Rio de Janeiro: Bertrand Brazil, pp. 19-45, 2001.

[3] Marques, A. \& Oaigen., E., The Chico Reis river pollution and its consequences to the public health, 2005.

[4] Britto, A.L. Implantação de infraestrutura de saneamento na região metropolitana do Rio de Janeiro: uma avaliação das ações do Programa de Despoluição da Baía de Guanabara. Brazilian Journal of Urban and Regional Studies, 5(1), pp. 63-77, 2011.

[5] Souza, L.G.R., Miranda, A.C. \& Medeiros, H.B., O lixo, o esgoto na baía de Guanabara e os programas de despoluição: a mídia versus os dados. Electronic Journal Environmental Forum of the Upper Paulista, 10(2), 2014.

[6] Ribeiro, J. \& Rooke, J., Saneamento básico e sua relação com o meio ambiente e a saúde pública. Juiz de Fora, MG, 2010.

[7] Pereira, J.A.R., Saneamento ambiental em Áreas urbanas. Belém: UFPA, EDUFPA, 2003.

[8] News Headline, G1, Online. Available at: http://g1.globo.com. Accessed on: Nov. 2016.

[9] Oashi, M.C.G., Estrutura, propriedades e aplicações das fibras naturais em tapetes, carpetes e geotêxteis, 1999.

[10] Winklerprins, A., Jute cultivation in the lower Amazon, 1940-1990: an ethnographic account from Santarém, Pará, Brazil. Journal of Historical Geography, 32(4), pp. 818-838, 2006.

[11] Mukhopadhyay, S. \& Khatana, S., A review on the use of fibers in reinforced cementitious concrete. Journal of Industrial Textiles, 45(2), pp. 239-264, 2015.

[12] Redação, Jornal Dia de Campo. O uso de fibras naturais para substituição de fibras sintéticas, Online. Available at: http://www.diadecampo.com.br/. Accessed on: Nov. 2016.

[13] Alves, C. et al., Ecodesign of automotive components making use of natural jute fiber composites. Journal of Cleaner Production, 18(4), pp. 313-327, 2010

[14] Diagnóstico situacional, ARCHITECH. Introdução sobre os igarapés de manaus e o corredor ecológico urbano do igarapé do mindu, Online. Available at: http://www.pram.mpf.mp.br/. Accessed on: Nov. 2016.

[15] Calheiros, V., Amazonas Atual, Online. Available at: http://amazonasatual.com.br. Accessed on: Nov. 2016.

[16] Brilhante, N., Amazônia, Online. Available at: http://amazonia.org.br/. Accessed on: Nov. 2016. 
[17] Amazonas TV, Online. Available at: http://redeglobo.globo.com/redeamazonica. Accessed on: Nov. 2016.

[18] Silva, R., Haraguchi, S.K., Muniz, E.C. \& Rubira, A.F., Applications of lignocellulosic fibers in polymer chemistry and in composites. New chemistry, 32(3), pp. 661-671, 2009.

[19] Moriwaki et. al., T.D.S. Utilização da fibra de bananeira como adsorvente em derramamento de petróleo, 2016

[20] Paiva, A.M., Agricultura camponesa: no contexto da produção de juta e malva na várzea do estado do Amazonas, Federal University of Amazon, 2009.

[21] Fagundes, M.H., Sementes de juta e malva: algumas observações, 2002.

[22] Redação RuralNews. Juta, cultura de grande valor econômico, Online. Available at: http://www.ruralnews.com.br. Accessed on: Nov. 2016.

[23] Araújo, M., Manual de Engenharia Têxtil, Online. Available at: http://www.kohlercia .com.br. Accessed on: Nov. 2016.

[24] Loumerem, M. \& Alercia, A., Descriptors for jute (Corchorus olitorius L.). Genetic Resources and Crop Evolution, 63(7), pp. 1103-1111, 2016.

[25] Begum, K. \& Islam, M., Natural fiber as a substitute to synthetic fiber in polymer composites: a review. Research Journal of Engineering Sciences, 2278, p. 9472, 2013.

[26] Fibras Naturais., Online. Available at: http://www.mixtextil.com. Accessed on: Nov. 2016.

[27] Otto, G.P. et al., Mechanical properties of a polyurethane hybrid composite with natural lignocellulosic fibers. Composites Part B: Engineering, 110, pp. 459-465, 2017.

[28] Rupp, A., Sustentabilidade Comunitária. As fibras naturais, Online. Available at: http://sustentacomuni.blogspot.com.br. Accessed on: Nov. 2016.

[29] Satyanarayana, et al., Estudo das características estruturais e propriedades de compósitos poliméricos reforçados com fibras de malva. State University of Northern Fluminense-UENF, Campos dos Goytacazes-RJ, 2013.

[30] Castilhos, L.F., Dossiê técnico. Aproveitamento da fibra de coco, Online. Available at: http://www.sbrt.ibict.br/dossie-tecnico/downloadsDT/NTY0MA==. Accessed on: Nov. 2016.

[31] Avelar, F.F., Utilização de fibras de piaçava (Attalea funifera) na preparação de carvões ativados, Federal University of Lavras, Lavras, 2008. 